\title{
LA GENERACIÓN DEL NOVECIENTOS Y LOS DISCURSOS DE IDENTIDAD
}

\author{
TEODOSIO FERNÁNDEZ
}

Francisco García Calderón, Ventura García Calderón, José de la Riva-Agüero y Víctor Andrés Belaúnde son sin duda los escritores más representativos de la generación peruana del novecientos, en buena medida olvidada. El éxito de José Carlos Mariátegui resultó letal para ellos: en los 7 ensayos de interpretación de la realidad peruana quedaron asociados para siempre con los criterios colonialistas de una historiografía «civilista» ya superada, representada sobre todo por De la Riva-Agüero, quien habría orientado a toda una generación universitaria en un sentido conservador y tradicionalista ${ }^{1}$. Luis Alberto Sánchez completaría la faena durante los años treinta, con las descalificaciones que habrían de encontrar forma definitiva en su Balance $y$ liquidación del novecientos. En la edición inicial de ese libro, publicada en Santiago de Chile en 1941, esas descalificaciones no mostraban la agresividad que alcanzarían después, cuando Sánchez integró para siempre a los novecentistas peruanos en una generación hispanoamericana cuyos "corifeos neoidealistas» luego virarían «hacia las dictaduras y el militarismo, hacia el fascismo y la plutocracia sin más ni más»².

Con sus escritos, los novecentistas peruanos parecen desmentir esos dictámenes. Irrumpieron en el ambiente cultural de su país cuando aún se sentían con intensidad los efectos de la derrota del Perú en la Guerra del Pacífico: «Nuestra generación aprendió entre ruinas y pobrezas que sólo podemos contar con nosotros mismos. Puede ésta definirse por un nacionalismo doloroso que hace recuento de los desastres y trata de reparar mentalmente lo que destruyeron otros» ${ }^{3}$, había de resumir Ventura García Calderón en
Nosotros, libro que «bien puede considerarse testamento del grupo» ${ }^{4}$. Enfrentados al desastre nacional, emprendieron el análisis de las deficiencias de la sociedad peruana, lo que los llevó a convertirse en sociólogos dedicados a analizar las enfermedades de aquel organismo enfermo y en historiadores capaces de averiguar el origen de los males. El pasado literario iba a convertirse de inmediato en un territorio de extraordinario interés para aquellas indagaciones.

Decididos a desarrollar un trabajo riguroso, los novecentistas apelaron a los planteamientos positivistas que entonces parecían garantizar resultados de validez científica. Caso significativo fue el de Belaúnde, quien, interesado en la reforma de los estudios universitarios de Derecho, en uno de sus primeros escritos puso en duda el derecho natural, entendido como «un conjunto de principios inmutables, grabados en la conciencia de todos $»^{5}$, que regiría las relaciones entre los hombres. En esa lógica, por considerarlos ajenos a la realidad, consideraba inaceptables tanto la existencia o posibilidad del estado natural como la identidad e igualdad de la naturaleza humana, postulados desmentidos por el poligenismo y el transformismo que entonces imponían sus tesis sobre los orígenes y la evolución del hombre. La observación se había convertido en el único método científico válido, también en el ámbito del Derecho y en los de otras ciencias morales o racionales, como la filosofía y la política, y desde luego en aquellas que el positivismo había generado, como la antropología y la sociología, o cuyo desarrollo había impulsado, como la psicología individual y colectiva, reclamando atención para factores como la historia, la

\section{Teodosio Fernández:}

Catedrático de literatura hispanoamericana de la Universidad Autónoma de Madrid. Su actividad docente e investigadora se ha centrado fundamentalmente en la literatura hispanoamericana de los siglos XIX y XX y la significación de los procesos políticos y culturales en ésta. Entre sus publicaciones se cuentan: El teatro chileno contemporáneo (1941-1973) (1982), La poesía hispanoamericana en el siglo XX (1987), La poesía hispanoamericana hasta el final del modernismo (1989), Los géneros ensayísticos hispanoamericanos (1990) y Literatura hispanoamericana: sociedad y cultura (1998), entre otras. Ha editado Amalia de José Mármol (1984), Huasipungo de Jorge Icaza (1994) y Garduña de Manuel Zeno Gandía (1996), así como el volumen Teoría y crítica literaria de la emancipación hispanoamericana (1997).

1

Véase José Carlos Mariátegui, 7 ensayos de interpretación de la realidad peruana, Lima, $\mathrm{Bi}$ blioteca «Amauta», 1928, pp. 97-101.

2

Luis Alberto Sánchez, Balance y liquidación del novecientos. ¿Tuvimos maestros en nuestra América?, Lima, Editorial Universo (4 ${ }^{a}$ ed.), 1973, p. 191.

3

Véase Nosotros (1946), en Ventura García Calderón, Obras escogidas, prólogo, selección y notas de Luis Alberto Sánchez, Lima, Ediciones Edubanco, 1986 (pp. 507-625), p. 543.

4

Francisco José López Alfonso, Prólogo a su edición de Indigenismo y propuestas culturales: Belaúnde, Mariátegui y Basadre, Alicante, Instituto de Cultura Juan Gil-Albert, 1995 (pp. 1152), p. 11.

5

«La filosofía del derecho y el método positivo» (1904), en Víctor Andrés Belaúnde, Obras completas I. El Perú antiguo y los modernos sociólogos y otros ensayos, Lima, Edición de la Comisión Nacional del Centenario, 1987 (pp. 1-43), p. 24 
6 Ibid., p. 27.

7

Le Pérou contemporain. Étude sociale, Paris, Dujarric et $\mathrm{Cie}$, Éditeurs, 1907, p. 25

8

«El Perú contemporáneo de Francisco García Calderón» (EI Ateneo, núm. 44, segundo semestre de 1907), en Víctor Andrés Belaúnde, Obras completas II. Meditaciones peruanas, Lima, Edición de la Comisión Nacional del Centenario, 1987 (pp. 9-19), pp. 14-15.

\section{9}

«La crisis presente», en Víctor Andrés Belaúnde, Obras completas II. Meditaciones peruanas (pp. 73-131), p. 79.

10

Ibid., p. 121.

11

«La crisis del Perú estriba en los factores psíquicos: la desviación de la conciencia nacional», en Víctor Andrés Belaúnde, Meditaciones peruanas, Lima, Compañía de Impresores y Publicidad Editores, 1932, pp. 7-20 (p. 14).

La generación del novecientos y los discursos de identidad TEODOSIO FERNÁNDEZ herencia y el medio ambiente, y proponiendo ideales para el progreso futuro. Ecos de $\mathrm{Au}-$ guste Comte parecen advertirse en Belaúnde cuando recordó que la cuestión religiosa, la cuestión política y la cuestión económica eran las que habían agitado sucesivamente y aún agitaban a la humanidad: "La cuestión religiosa abraza toda la edad media. La cuestión política, el advenimiento y constitución de las nuevas nacionalidades, toda la edad moderna y gran parte de la contemporánea; y hoy, como dice muy bien el profesor Aquiles Loria, prima sobre todas las cuestiones la cuestión económica» ${ }^{6}$. Ese sociólogo y economista italiano era por entonces otra autoridad reconocida, y ayudó sin duda a Belaúnde y a Francisco García Calderón -a través de Le bassi economiche della costituzione sociale y de Problèmes sociaux contemporains, probablemente- a identificar los factores económicos que determinaban los fenómenos sociales e incluso a entrever la influencia de esos factores en la crisis de valores o decadencia moral de su tiempo.

El optimismo pareció impregnar los primeros esfuerzos para adentrarse en la realidad peruana. Francisco García Calderón la abordó cuando, tras una década de paz, el país parecía haber encontrado la senda del progreso político y social. «Le but de ce livre est d'esquisser ce progrès et de démontrer les superbes perspectives de notre avenir, dans l'évolution du continent américain et dans la marche de la race latine» ${ }^{7}$, anticipaba en Le Pérou contemporain. Su análisis de la historia republicana, de la evolución de las ideas y de los hechos, de las fuerzas políticas y económicas, entre otros factores, le permitieron adivinar un futuro grandioso. Como Belaúnde explicaría al comentarlo, el libro se ajustaba al «patriotismo moderno», menos interesado en el pasado que en el porvenir: «no es el entusiasmo o el respeto y el amor a lo que fue, es el ansia, el anhelo, la inquietud por lo que ha de ser; o mejor todavía, se halla en el consorcio de una tradición "viva" y de un ideal que surge de la misma tradición» ${ }^{8}$. Ciertamente, Francisco García Calderón no dejó de observar aspectos negativos en la historia y en la psicología nacional, que otros analizarían con más detalle. Con obras como El problema nacional, de Ricardo Macías Picavea, o Colectivismo agrario en España y otras de Joaquín Costa, los regeneracionistas españoles sin duda animaron a Belaúnde a denunciar en breves «ensayos de psicología nacional», publicados en 1912 en la revista Ilustración Peruana, la incoherencia individual y colectiva, los rencores disolventes y esterilizadores, la ironía degradada a burla, la ignorancia agresiva e infatuada, la preferencia por lo decorativo frente a lo útil y la pobreza de sentimientos como limitaciones de la psicología nacional. En abril de 1914, al inaugurar el curso académico en la Universidad de San Marcos, analizaría detalladamente y ya sin optimismo el difícil momento económico, político y moral que atravesaba aquel «grande y amado enfermo» ${ }^{9}$ que era el Perú -un levantamiento militar acababa de poner fin al gobierno del presidente Guillermo Billinghurst-, reafirmando su compromiso con una regeneración de profunda significación ética: «trabajo y moralidad, sentimiento de la acción, filosofía pragmática, tal debe ser nuestra orientación» ${ }^{10}$, propuso a la vez que lamentaba la desaparición del entusiasmo y de los ideales que habían impregnado la lucha por la independencia y en buena medida la actividad de los políticos del siglo XIX. Se trataba de robustecer el sentimiento nacional con el amor a la tierra y a los muertos, y de constituir una minoría superior, una oligarquía intelectual capaz de imponer sus virtudes y su talento.

El estallido de la guerra europea probó a Belaúnde que los factores éticos, mentales o espirituales podían determinar el curso de los hechos tanto o más que los económicos, geográficos y étnicos. Cuando en 1917, en el diario limeño El Perú y bajo el epígrafe $L a$ realidad nacional, volvió sobre las dolencias del país con nuevos ensayos, abordó una enfermedad que entonces ya creía principalmente psíquica, derivada de la carencia de ideales arraigados en la tierra peruana: "Anatopismo es la expresión que indica mejor el vicio radical de las aspiraciones colectivas. En la historia del Perú el alma nacional o dormita, sin querer nada, o despierta para orientarse en el sentido de lo irrealizable o de lo equivocado. Es nuestra vida una triste sucesión de anatopismos» ${ }^{11}$. Era ése un mal cuyo remedio años antes había esperado de los estudios históricos. Ahora advertía que en las aportaciones de Francisco García Calderón y José de la Riva-Agüero había pasado desapercibido el defecto peruano fundamental: la pobreza de sentimiento. Al calor del sentimiento brotaría la intuición, que se mostraba como la vía apta para descubrir los aspectos «misteriosos 
y velados de las cosas» ${ }^{12}$. La difícil geografía peruana ya no era un factor determinante del fracaso nacional, y tampoco lo era la composición étnica, aunque también él reiteradamente volviera sobre las peculiaridades psicológicas de indios y mestizos. Pero la hora de las ilusiones había pasado: la salvación del Perú parecía difícil, obstaculizada por un régimen político personalista sujeto a los intereses de la plutocracia de la costa, de la burocracia militar y del caciquismo parlamentario, y apoyado por esos mismos intereses.

La evolución de Belaúnde sólo es una muestra de la variedad de planteamientos y propuestas que su generación fue capaz de ofrecer en las primeras décadas del siglo XX, afectada por corrientes ideológicas diferentes y aun contrapuestas. El positivismo de los novecentistas se había visto profundamente afectado por las orientaciones vitalistas y espiritualistas del pensamiento contemporáneo. Entre éstas se contó el arielismo, que alguna vez fue objeto de críticas severas: De la RivaAgüero incluyó a José Enrique Rodó entre los «optimistas simpáticos» e «incorregibles soñadores» del momento, al proponer la Grecia antigua como modelo para una raza contaminada de indios y negros, frívola y perezosa. «Francamente, si la sinceridad de Rodó no se transparentara en cada una de sus páginas, era de sospechar que Ariel ocultara una intención secreta, una sangrienta burla, un sarcasmo acerbo y mortal» ${ }^{13}$, escribió en Carácter de la literatura del Perú independiente, análisis que concluiría recomendando a los hispanoamericanos el pragmatismo que les permitiría competir con los norteamericanos y merecer su respeto, y al Perú fomentar la inmigración europea que por entonces parecía dar a la Argentina una condición privilegiada en el ámbito de Hispanoamérica. En el desarrollo de la industria y el comercio radicaba para él la posibilidad de salvar la autonomía de los países hispanoamericanos, a la vez que en el aumento de la población de origen español e italiano veía el medio para fortalecer el predominio de la raza latina en el territorio nacional.

Reticencias como ésas no impidieron que el entusiasmo arielista encontrara numerosas ocasiones para manifestarse, y de ello dejó constancia sobre todo Francisco García Calderón, al menos desde que en 1904 publicó De litteris (crítica) con un prólogo elogioso de Rodó, a quien consideraba «verdadero guía de espíritus» ${ }^{14}$. Ensayos allí incluidos, como «Sobre Fernando Brunetière», mostraban a su autor consciente de vivir en un tiempo marcado por la bancarrota de la ciencia y por el regenerador renacimiento espiritualista, y decidido a ver en Herbert Spencer «un grande y sereno idealista, un positivista que tiene su ensueño, sus grandes visiones y hasta su utopía»15. También García Calderón trataba de lograr esa conciliación, y la relacionó con el fin de los males que aquejaban a las repúblicas hispanoamericanas. "Estamos en pleno renacimiento de idealismo", aseguraba esperanzado en Heidelberg, durante el congreso de filosofía en el que participaba en septiembre de 1908, en un ensayo que -en traducción anotada de Pedro Henríquez Ureña, publicada en noviembre de ese año en la Revista Moderna de México e incluida en Profesores de idealismo- había de tener notable difusión en los países hispanoamericanos $^{16}$. Ecos arielistas reflejó luego en Les démocraties latines de l'Amérique, tanto al recordar al admirado maestro uruguayo como al analizar las diferentes consecuencias que el individualismo y el idealismo habían dejado en las respectivas historias de Inglaterra y de España, y precisamente en el aspecto que más parecía afectar a sus respectivos herederos americanos: «dans la conquête d'un milieu hostil, le Saxon adquiert un sens réaliste; et l'Ibère, sous un ciel amoureux, se transforma, en Espagne comme en Amérique, en chasseur de quimères. Un symbole consacre la ressemblance des deux histoires: Ariel et Caliban ${ }^{17}$. El análisis de las características psicológicas de los hispanoamericanos descubría en ellos inevitablemente la herencia española: al cabo, «le créole d'outre-mer est un Espagnol du siècle héroïque, énervé par le métissage et le climat. Imposible d'expliquer son caractère sans tenir compte du génie espagnol» ${ }^{18}$. Desde luego, Francisco García Calderón se contaba entre quienes relacionaban la raza latina con una identidad cultural, y no con peculiaridades étnicas ${ }^{19}$, aunque a la hora de valorar cualidades y defectos reiterara sus reticencias ante la capacidad de indios, negros, mestizos y mulatos para impulsar la estabilidad política y el desarrollo económico hispanoamericano. Esos obstáculos no debilitaban su confianza en el futuro, que inspiraría también La creación de un continente, donde defendió un americanismo latino frente al panamericanismo potenciado por Estados Unidos y frente
12

"Deficiencias en la cultura nacional», en Meditaciones peruanas, (pp. 21-34), p. 24.

13

Carácter de la literatura del Perú independiente, Tesis para el Bachillerato de Letras, Lima, Librería Francesa Científica Galland, E. Rosay Editor, 1905, pp. 262-263.

\section{4}

Véase "Una nueva manera de crítica», en Francisco García Calderón, De litteris (crítica), Lima, Librería e Imprenta Gil, (pp. 15-23), p. 22. En la "platónica disertación» Ariel había de encontrar grandes principios que deberían «invadir a toda alma joven de América». Véase "Ariel y Calibán», en Francisco García Calderón, Hombres e ideas de nuestro tiempo, Valencia, F. Sampere y Compañía, Editores, 1907 (pp. 189-199), p. 197.

15

"Herbert Spencer», en Francisco García Calderón, De litteris (crítica), op. cit. (pp. 59-86) p. 84 .

16

Véase "Las corrientes filosóficas en la América Latina», en Francisco García Calderón, Profesores de idealismo, París, Sociedad de Ediciones Literarias y Artísticas, Librería Paul Ollendorff, 1909 (pp. 149-162), p. 160. García Calderón lo incluiría también en Ideas e impresiones (Madrid, Editorial América, 1919, pp. 41-57), antología de sus ensayos precedida de un estudio de Gonzalo París.

17

Francisco García Calderón, Les démocraties latines de I'Amérique, Paris, Ernest Flammarion, Éditeur, 1912, p. 17.

18 Ibid., p. 14.

19

«ll y a une civilisation latine, une âme latine: il n'y a pas de race latine». Le Pérou contemporain. Étude sociale, p. 33.

\footnotetext{
La generación del novecientos y los discursos de identidad TEODOSIO FERNÁNDEZ
} 


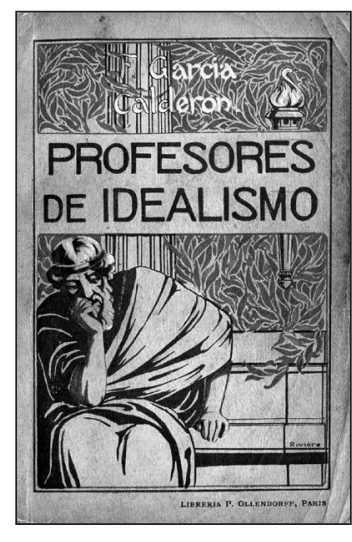

20

Francisco García Calderón, La creación de un continente, París, Sociedad de Ediciones Literarias y Artísticas, Librería Paul Ollendorff, 1913, p. 262. Tras estallar la primera guerra mundial, García Calderón prefirió centrar su atención en la actualidad de la política y la cultura europeas, como demuestran los ensayos que fue reuniendo en Ideologías (1918), El dilema de la gran guerra (1919), Europa inquieta (1926) y La herencia de Lenin y otros artículos (1929).

21

"La historia», en Víctor Andrés Belaúnde, Obras completas II. Meditaciones peruanas (pp. 21 $37)$, p. 23.

22

José de la Riva-Agüero, La historia en el Perú, Lima, Imprenta Nacional de Federico Barrionuevo, 1910, p. 8.

23

Francisco García Calderón Les démocraties latines de l'Amérique, op. cit., p. 13.

24

lbid., p. 71.

25

lbid., p. 73.

26

lbid., p. 13.

27

lbid., p. 47.

28

Carácter de la literatura del Perú independiente, op. cit., p. 68.

La generación del novecientos y los discursos de identidad TEODOSIO FERNÁNDEZ al paniberismo que mutuas reticencias e ignorancias entre España y sus antiguas colonias hacían aún inviable. El análisis de los progresos recientes concluía con la proclamación de una fe ilimitada en el porvenir de esa América «desmesurada y pródiga» de estirpe latina: «Quizás está ella destinada, desde el origen de los tiempos, a que en sus amplias mesetas nazca, hijo del Sol, como en la leyenda de los Incas imperiales, señor de las cumbres orgullosas y de los ríos tutelares, avasallador y solitario, el Superhombre» ${ }^{20}$.

Los estudios históricos de los novecentistas peruanos fueron consecuentes con las preocupaciones que impulsaban el análisis sociológico y psicológico de la sociedad peruana, $\mathrm{y}$ siguieron un proceso también significativo. De la importancia que les atribuyeron dio una excelente muestra Belaúnde en el discurso que el 13 de diciembre de 1908 pronunció en el Instituto Histórico: «La historia es una liberación. El pasado desconocido vive en la subconsciencia de los pueblos, pesa con sofocante gravedad en su marcha evolutiva» ${ }^{21}$, aseguró, para después explicar que la revelación de ese pasado era imprescindible para que un pueblo fuese consciente de sus impulsos hereditarios y dueño de sus tradiciones, para que adquiriese conciencia nacional y con ella los ideales y las aspiraciones propios que pudieran orientarlo hacia la innovación y el progreso. De la Riva-Agüero se ocupó en La historia en el Perú de los historiadores nacionales con la pretensión declarada de investigar «las cualidades que para la historia ha revelado el ingenio peruano» ${ }^{22}$, y los novecentistas se entregaron a la tarea de examinar el pasado a la luz del pensamiento moderno. Los planteamientos positivistas de Spencer se dejaban sentir cuando Francisco García Calderón, refiriéndose en Les démocraties latines de l'Amérique a los tiempos que siguieron a la independencia, señalaba que «deux périodes, l'un d'anarchie militaire, l'autre d'ordre intérieur, de richesse, d'industrialisme, se succèdent dans les nouveaux États» ${ }^{23}$, antes de recordar otras opiniones que reforzaban su visión de una América convulsionada por la lucha entre la autoridad y la libertad, y donde la Revolución (el paso de período a otro) «se réduit à un changement d'oligarchies; le groupe militaire céde la place à la ploutocratie» ${ }^{24}$. Tales planteamientos no le impedían constatar que la consecuencia hispanoamericana más visible de la anarquía era la aparición de tiranos capaces de imponer el orden, dictadores que profesaron el americanismo en el plano político y en el económico, e incluso «fondent les démocraties: ils s'appuient généralement sur le peuple, sur les métis et les nègres, contre les oligarchies; ils dominent la noblesse coloniale, favorisent le croisement des races, affranchissent les esclaves» ${ }^{25}$. En tales condiciones era difícil precisar el paso del período militar al período industrial en no pocos países, pues a menudo el cambio estaba ligado precisamente a la acción de caudillos pacificadores, cuyo mejor ejemplo y reciente había sido el de Porfirio Díaz y México. Una ley de la historia parecía comprobarse reiteradamente: «la dictature est le gouvernement adéquat pour créer l'ordre intérieur, développer la richesse, et unifier les castes ennemies» ${ }^{26}$. Se podía, pues, mostrar la faceta bienhechora de los tiranos, y estudiar la historia de cada país a la luz de esos hombres representativos y aun reducirla a ellos. Su formación positivista y su análisis de los males nacionales llevaron así a los novecentistas, con la probable colaboración de los regeneracionistas españoles, a manifestar su interés por soluciones políticas de orden, incluso por las que nunca se adoptaron en el caótico pasado del Perú y de Hispanoamérica: «La monarchie offrait à l'Amérique stabilité et indépendance; elle eût empèché les guerres civiles et évité un demi-siècle d'anarchie» ${ }^{27}$, opinaba Francisco García Calderón al rememorar las luchas que pusieron fin al dominio español. También De la Riva-Agüero mostró preferir la orientación monárquica de José de San Martín a los ideales republicanos de Simón Bolívar, antes de que sus opiniones sobre la obra literaria de Felipe Pardo y Aliaga le dieran pie para lamentar el caos de la vida republicana: «Lo que le faltó al Perú para ahorrarse tan penosa infancia, fue una autoridad robusta, férrea, que domara la anarquía, que hiciera lo que Portales hizo en Chile, lo que Díaz hace en México, lo que aquí no lograron ni Vivanco ni Castilla» ${ }^{28}$. El proceso político peruano pronto les haría cambiar de opinión: en cuanto algunos de ellos trataron de convertir en acción política su voluntad regeneradora, los centenaristas pudieron descubrir la cara oscura de esos gobiernos personalistas. El Partido Nacional Democrático, que De la Riva-Agüero fundó en 1915 y al que perteneció Belaúnde, se vio hostilizado de inmediato por el gobierno civilista que entonces dirigía el presidente José Pardo y Barreda, y su 
situación habría de agravarse tras el pronunciamiento de Augusto B. Leguía, que en julio de 1919 puso fin a la república «aristocrática». Belaúnde, el más activo, estaba ya lejos de las posiciones positivistas de antaño y a la vez del cesarismo político que con frecuencia su generación había valorado positivamente. Contra las mediocres manifestaciones peruanas de ese cesarismo dirigía su actividad política, interrumpida cuando las circunstancias lo llevaron en 1919 a abandonar su cargo diplomático y en 1921 a la prisión y al destierro.

«Yo veo mi patria en las ruinas de la civilización de las razas primitivas; ruinas que al caer la tarde insinúan el silencioso poema de su melancolía», había escrito tempranamente Belaúnde ${ }^{29}$. La necesidad de remontar la investigación del presente hasta los orígenes de la nación exigió prestar atención a los tiempos prehispánicos, que ahora iluminaban los hallazgos arqueológicos: «Las ruinas de Tiahuanaco, las chulpas del Collao, los restos de Cuélap y Huánuco Viejo, los muros de Chanchán, los utensilios hallados en la costa, nos obligaban a rectificar las antiguas creencias $»^{30}$, recordaba Belaúnde en El Perú antigno y los modernos sociólogos, tratando de ser objetivo en un debate enturbiado desde posiciones nacionalistas y socialistas ${ }^{31}$. En efecto, hasta finales del siglo XIX se había discutido sobre todo en torno a los aspectos moralmente positivos o negativos del Incario, enfrentando a los partidarios de la libertad con los defensores de la organización comunista. De la RivaAgüero había dado a conocer ahora -en 1906 y 1907 en la Revista Histórica y como libro en 1908, antes de incorporarlo a La bistoria en el Perú-Examen de la primera parte de los «Comentarios reales», trabajo en el reivindicó el valor histórico de la obra del Inca Garcilaso de la Vega, no tanto para defender su visión idílica del mundo incaico como para contrarrestar las opiniones negativas que sobre la fiabilidad de sus escritos se había difundido sobre todo después de que en 1882 se publicasen las Memorias antiguas bistoriales $y$ politicas del Perú, de Fernando Montesinos, seguidas de Informaciones acerca del señorio y gobierno de los Ingas hechas por mandado de don Francisco de Toledo, virrey del Perú, 1570-1572, de donde se deducía la existencia de un imperio preincásico a la vez que se cuestionaba la significación civilizadora de un Incario tiránico y opresor. Consecuente con la visión novecentista de la historia repu-

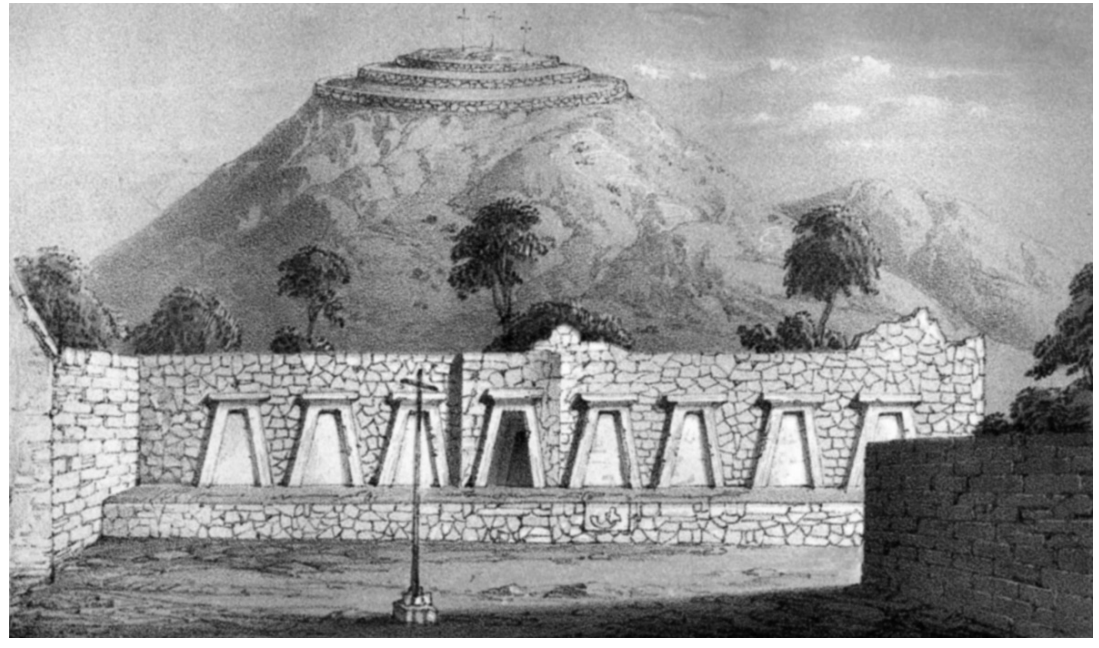

Palacio de Manco Cápac.

blicana, Belaúnde apreciaba la «minuciosa y benefactora» ${ }^{32}$ tiranía incaica, respetuosa con los ritos y costumbres de los pueblos vencidos, y desde su perspectiva jurídica repasaba distintas teorías sobre el Perú prehispánico y sus instituciones, para detenerse sobre todo en Spencer, que en Principles of Sociology había considerado el imperio de los Incas como el mejor ejemplo de sociedad militar. Belaúnde señaló en esos planteamientos tanto los aciertos como las carencias, en especial la que se refería al sistema de propiedad, aspecto que creía fundamental para explicar la estructura social y política del Incario. Con la ayuda de las teorías «modernas» del alemán Heinrich Cunow y del belga Guillaume De Greef -y tras los pasos del peruanista Clements R. Markham, de Bautista Saavedra, que como boliviano daba en El ayllu (estudios sociológicos) un origen aymara y preincaico a la comunidad indígena original, y de De la Riva-Agüero, quien consideraba quechua la civilización preincaica de Tiahuanaco-, concluyó que la organización comunista no guardaba relación con el régimen militar incaico, sino con la supervivencia de formas igualitarias de las tribus sometidas, formas que el Incario respetó y aprovechó a la vez, dándoles caracteres plenamente definidos. La originalidad del comunismo incaico anclaba así sus raíces en el pasado más remoto, y las conclusiones de Spencer sobre su carácter estrictamente militar quedó en entredicho. El positivismo de Belaúnde comenzaba a vacilar: había comprobado que la observación de los hechos podía dar lugar a teorías o doctrinas a las que no tenían por qué ajustarse otros
29

«La historia», p. 37

30

El Perú antiguo y los modernos sociólogos (1908), en Víctor Andrés Belaúnde, Obras completas I. El Perú antiguo y los modernos sociólogos y otros ensayos (pp. 45-134), p. 65.

31

«Dos cosas pueden perturbar el criterio al juzgar la vieja civilización: las ingenuas exaltaciones de un nacionalismo retrospectivo; y el deseo de encontrar en el viejo Perú barato arsenal de razones a favor de la tesis socialista, o en contra de ella, por la cruel supresión de la libertad humana. No coloquemos muy en la entraña de nuestro sentimentalismo patriótico la organización pre-hispánica, y sobre todo no moralicemos sobre ella». Ibid., p. 133

32

lbid., p. 18.
La generación del novecientos y los discursos de identidad TEODOSIO FERNÁNDEZ 
33

No dejaría de recordar que "el sistema de los Incas no era destructivo sino constructivo; su política no era radical, sino evolutiva». Subrayaba así las diferencias entre el sabio comunismo incaico y la violencia destructora de la Rusia soviética. Véase «Comunismo incaico y bolchevismo» ("Incan communism and bolchevism», The Rice Institute Pamphlet, Houston, Texas, octubre de 1923), en Obras completas 1. El Perú antiguo y los modernos sociólogos y otros ensayos, op. cit. (pp. 187-204), p. 198.

34

«La filosofía del derecho y el espíritu positivo» en op. cit., p. 40.

35

"La historia», en op. cit., p. 37.

36

Le Pérou contemporain. Étude sociale, op. cit., p. 23.

37

«La race espagnole apporta à cette lutte le goût de la aventure, l'heroïsme épique, l'individualisme excessif, le fanatisme et la cupidité audacieuse et sanglante. Cette étape est une epopée, par l'énergie, par le sentiment religieux, qui agit comme deus ex machina, par la disproportion entre les moyens et les buts, par un suffle de race qui anime et pousse les hommes á lutter et à conquérir, contre la nature inconnue, contre l'Indien mal soumis». Ibid., p. 22.

38

«La historia», en op. cit., p. 36.

39

«La crisis presente», en op. cit., pp. 130 y 131 .

40

«Basta decir que por el año 1777-79, había quien se titulaba teniente del Rey del Paititi y soñaba con la conquista del fabuloso imperio; cosa por cierto que no es de extrañar si se recuerda, como dice Humboldt, que el Dorado fue perseguido hasta 1775. A lo que puedo agregar que he tenido en mis manos un expediente sobre la misma entrada del Dorado del año de 1779, es decir, 30 años antes de la independencia». Véase "Los mitos amazónicos y el imperio incaico», en Obras completas I. El Perú antiguo y los modernos sociólogos y

La generación del novecientos y los discursos de identidad

TEODOSIO FERNÁNDEZ hechos o los mismos cuando se examinaban con otras luces. En adelante preferiría apreciar en los Incas tanto su capacidad para asimilar el pasado como la fuerza creadora que había dado a su imperio una personalidad definible como «nacional» ${ }^{33}$. Muy lejos quedaba ya el Belaúnde que había proclamado el fin de los ideales religioso y nacionalista, y que apoyarlos «sería destruir toda la obra de la civilización» ${ }^{34}$.

Otro motivo de especial atención fue el pasado español: «Yo veo mi patria en la enmohecida armadura de los conquistadores, ávida de recibir pechos de igual empuje; en la severa mirada autoritaria de los virreyes bajo los graves birretes o las pelucas empolvadas», escribió también Belaúnde ${ }^{35}$. Ese interés no impidió que inicialmente los novecentistas abordaran aquel pasado con las reticencias propias de sus planteamientos positivistas, que llevaron a De la Riva-Agüero, en Carácter de la literatura del Perú independiente, a identificar el espíritu que sustentaba las manifestaciones culturales del país con el criollismo, degeneración de la virilidad y energía del carácter español determinada por el clima tibio y húmedo de la costa peruana, por el servilismo y la molicie del régimen colonial y por la confluencia de indios y negros, cuyas contribuciones a la literatura estimó irrelevantes, y no sólo para el Perú. La energía viril demostrada por los conquistadores y su degradación posterior permitían comprobar los efectos del medio sobre la raza y a las vez distinguir dos etapas en el período colonial: «A l'époque guerrière, succède une période longue, monotone et fastueuse, la Colonia. Et dans un climat tempéré et énervant, la grande race del dominateurs s'affaiblit et s'epuise», confirmaría Francisco García Calderón» ${ }^{36}$. Consecuentes con ese planteamiento, los novecentistas contrastarían reiteradamente la etapa épica de la conquista, una epopeya heroica y brutal ${ }^{37}$, con el período propiamente colonial, cuya chata o deslucida existencia dejaba patente la decadencia española bajo la presión del clima y el contacto de los pueblos vencidos. Ambos períodos habrían dejado herencia perdurable: «El genio rebelde y audaz

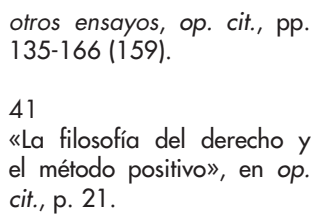

41

«La filosofía del derecho y el método positivo», en op. cit., p. 21.

de los conquistadores produjo las antiguas tiranías, de las cuales no son sino remedo los desplantes de nuestro moderno caudillismo. Al antiguo absolutismo, a la vieja manía ordenancista, corresponden nuestra moderna estatolatría y nuestro furor legislativo y reglamentario», constataba Belaúnde ${ }^{38}$. Con el tiempo, sin embargo, los novecentistas peruanos participaron de una nueva visión de la actuación española en América que iba ganando adeptos entre los intelectuales hispanoamericanos: «Aun tratándose de los mismos conquistadores, más que sed de oro, estaban ebrios de un sueño heroico», escribía Belaúnde a la vez que apuntaba la necesidad de revisar la leyenda que veía en la colonización de América «sólo privilegios y explotación» ${ }^{39}$. Él mismo demostró un notable interés en los mitos de la conquista, como permite comprobar el artículo «Los mitos amazónicos y el imperio incaico», donde constató la fuerza y la prolongada vigencia que algunos tuvieron ${ }^{40}$. En su caso leyendas como la del Paititi sirvieron también para argumentar las relaciones del Incario con los territorios situados al este que explicaría en «Las expediciones de los incas a la hoya amazónica», publicado como el anterior en 1911, en la Revista Universitaria de la Universidad Mayor de San Marcos.

El interés por el pasado virreinal también se dejó sentir, y alguna vez, además, ese pasado pareció competir ventajosamente con el infausto presente. «El amor a lo viejo por la única razón de ser viejo, será todo lo poético que se quiera; pero no es propio de espíritus científicos» ${ }^{41}$, advirtió Belaúnde pocos años antes de que la actualidad política peruana le llevase a afirmar que «el presidente de la república es un virrey sin monarca, sin Consejo de Indias, sin oidores y sin juicio de residencia» ${ }^{42}$ : sin controles que pudieran poner límites a su autoridad o a sus desmanes. Incluso para los indios hubo tiempos mejores, pues el Perú republicano había sido incapaz de ofrecer algo comparable a las Leyes de Indias que los habían protegido, como Belaúnde habría de recordar en el Teatro Nacional de Arequipa, en 1915, en su campaña por la diputación de aquella provincia. Los novecentistas no fueron inmunes a la poesía que parecía impregnar el pasado, incluso aquellos tiempos coloniales en los que la vida se desarrollaba «grave et monotone» en ciudades que «sommeillent bercées par le murmure des prières et des fontaines» ${ }^{43}$. Pero, frente a esa visión 
uniforme y simplificadora del mundo colonial que incluso Mariátegui compartió, trataron de conocerlo mejor y sus esfuerzos les permitieron descubrir en la colonia una inesperada variedad de momentos históricos y culturales: «Hay en ésta la época heroica, la época jurídica, la de consolidación, la de decadencia y la de reforma. De modo que hay una literatura épica, una literatura jurídico-política, una literatura cortesana y devota y una literatura social», precisaría Belaúnde antes de afirmar que la cultura peruana, desde sus comienzos, era «esencialmente nacional» ${ }^{4}$.

Los novecentistas peruanos vieron la literatura como un fenómeno social, una manifestación de la psicología individual y colectiva en la que trataban de adentrarse, a la vez que intentaban conquistar un espacio propio. «Pobre generación sin maestros, generación solitaria y ferviente a quien le dieron a porfía los malos ejemplos de una retórica apolillada, un desdén iracundo a todo y una ampulosidad vecina del mal gusto», se lamentaría Ventura García Calderón al rememorar la suya ${ }^{45}$. La ampulosidad vecina del mal gusto era la de José Santos Chocano, cuyo «continentalismo», en opinión de Belaúnde, repugnaría al «nacionalismo» que con sobriedad y sentimiento del ambiente físico y humano propio lo hubiera convertido en poeta representativo del Perúu ${ }^{46}$. Más atención dedicaron los novecentistas al desdén iracundo de Manuel González Prada, cuyo radicalismo resultaba incompatible con la adhesión a las doctrinas del orden y del progreso que ellos a su modo profesaron. "No nos reduzcamos a deplorar el mal: realicemos el bien. No nos empeñemos en destruir: edifiquemos», proclamaba De la Riva-Agüero subrayando las diferencias que alejaban al autor de Páginas libres de quienes aún confiaban en salvar algo de «este naufragio de ilusiones y esperanzas que se llama historia de la República del Perú» ${ }^{47}$. Se trataba de mantener la fe en el futuro, aun contra los datos suministrados por la razón y la experiencia. Luego el alejamiento aumentaría a medida que los novecentistas acentuaban sus inclinaciones idealistas y vitalistas a costa del pragmatismo inicial, cuestionando la relevancia de los factores económicos, y quizá culminó cuando Belaúnde, muy interesado ya en las últimas teorías filosóficas sobre el fenómeno religioso, señaló la índole dogmática del anticlericalismo, que parecía constituir el núcleo ideológico de González Prada. Eso no impediría al propio Belaúnde reconocer en él, entre otros valores, el de representar, tras la guerra del Pacífico, «la expresión más profunda y bella del sentimiento nacional, desgarrado y sangrante, después de la derrota y de la mutilación territorial» ${ }^{48}$.

La retórica apolillada era la de Ricardo Palma, cuya simpatía hacia la colonia -conjunción de sentimiento e intuición, que le permitió rescatar viva y cálida el alma del pasado- finalmente habría de convertir las Tradiciones en «un libro esencial en el patriotismo peruano ${ }^{49}$. Antes de que alcanzaran esa condición, su autor ya había sido reputado por De la Riva-Agüero como «el representante más genuino del carácter peruano», «el escritor representativo de nuestros criollos ${ }^{50}$, no sin advertir tanto su incapacidad para sentir con intensidad la poesía de los tiempos prehispánicos como su condición limeña más que peruana, aunque también prestara atención a las tradiciones populares de la sierra. Fue De la Riva-Agüero precisamente quien, a propósito de Palma y de su fascinación por la vida colonial, explicó ese interés que los novecentistas compartieron: sin que el encanto de la colonia impidiera al sociólogo y al político advertir la herencia nefasta que aquel período de indolencia legaría al futuro Perú, el historiador de los procesos literarios y artísticos podía sentir que «toda época, aun la más prosaica y muerta en apariencia, resulta poética por el hecho de ser pasada» ${ }^{51}$. En la Lima contemporánea aún estaba presente algo de la colonia, cuya rememoración adquiría así el encanto de lo castizo, de lo propio, de lo entrañablemente familiar.

$\mathrm{Si}$ algún escritor pudo compartir con $\mathrm{Pal}-$ ma la capacidad para la captación del alma nacional en su realidad geográfica e histórica, ese fue el Inca Garcilaso de la Vega. Belaúnde habría de llegar a una conclusión que en sus inicios hubiera considerado anticientífica, tanto por esencialista o metafísica como porque sus convicciones transformistas de entonces excluían cualquier consideración sobre la identidad, incompatible con la evolución de esa entidad psíquica que es el hombre $\mathrm{y}$ de ese todo psíquico que es una sociedad ${ }^{52}$ : su obra no se concebía «sino engendrada por el afecto profundo a la tierra y a la historia», era fruto no de la inteligencia analítica sino de la intuición, lo que hacía del Inca «el primer maestro de patriotismo y la primera fuente de sentimiento nacionalista» ${ }^{53}$. El ámbito

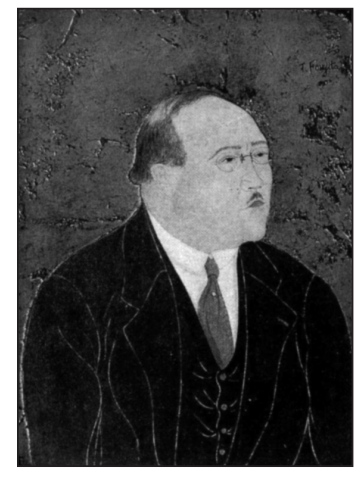

Ventura García Calderón.

44

La realidad nacional, París, Editorial «Le Livre Libre», 1931, pp. 142 y 145

45

Véase Nosotros, en op. cit., p. 541 .

46

«Deficiencias en la cultura nacional», en op. cit., p. 29.

47

Carácter de la literatura del Perú independiente, en op. cit., p. 214.

48 La realidad nacional, en op. cit., p. 163.

49

"Deficiencias en la cultura nacional», en op. cit., p. 32.

50

Carácter de la literatura del Perú independiente, op. cit., $\mathrm{p}$. 129.

51

Ibid., p. 147

52

"La filosofía del derecho y el método positivo», en op. cit., pp. 26 y 38.

53

"Deficiencias en la cultura nacional», en op. cit., p. 31 . La generación del novecientos y los
discursos de identidad TEODOSIO FERNÁNDEZ 


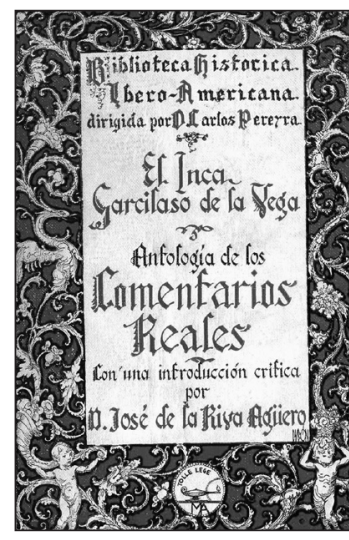

54

José de la Riva-Agüero, "Elogio del Inca Garcilaso en el tercer centenario de su muerte», introducción crítica a El Inca Garcilaso de la Vega, Antología de los "Comentarios reales», Madrid, M. Aguilar, Editor, 1929, pp. 43-44.

55

José de la Riva-Agüero, Paisajes peruanos, con un «Estudio preliminar» de Raúl Porras Barrenechea, Lima, Imprenta Santa María, 1955, p. 113.

56

José de la Riva-Agüero, El Perú histórico y artístico. Influencia y descendencia de los montañeses en él, Santander, Sociedad de Menéndez y Pelayo, 1921, p. 34.

57

De la Riva-Agüero, «Elogio del Inca Garcilaso en el tercer centenario de su muerte», op. cit., p. 54.

\section{8}

José de la Riva-Agüero, Examen de la primera parte de los "Comentarios reales» de Garcilaso Inca de la Vega (fragmento de un ensayo sobre los historiadores peruanos), Lima, Edición tipográfica de La Opinión Nacional, 1908, p. 136

59

Carácter de la literatura del Perú independiente, op. cit., $\mathrm{p}$. 220.

60

lbid., pp. 226-227.

61

Ibid., p. 244.

La generación del novecientos y los discursos de identidad TEODOSIO FERNÁNDEZ cognoscible de los hechos o los fenómenos ya se conjugaba para entonces con el de la especulación metafísica, de las sustancias y las esencias. Así pudo De la Riva-Agüero encontrar en Comentarios reales la «eterna dulzura» de la patria, identificada en «la mansedumbre de sus vicuñas, la agreste apacibilidad de sus sierras y la molicie de sus costeños oasis», y la entraña del sentimiento peruano en «ese aire de pastoral majestuosa que palpita en sus páginas y que acaba en el estallido de una desgarradora tragedia, ese velo de gracia ingenua tendido sobre el espanto de las catástrofes, lo dulce junto a lo terrible, la flor humilde junto al estruendoso precipicio, la sonrisa resignada y melancólica que se diluye en lágrimas» ${ }^{54}$.

De la Riva-Agüero contaba con un conocimiento más profundo de esa patria desde que en 1912 realizó un viaje a la sierra, del que derivarían algunos escritos parcialmente difundidos a partir de 1916 y reunidos en Paisajes peruanos ya en 1955, once años después de su muerte. En ellos, mientras afirmaba su convicción de que el período colonial formaba parte de la historia del Perú -no se podían amputar del concepto de patria «los tres siglos civilizadores por excelencia» ${ }^{55}-$, incorporó a la literatura nacional un territorio apenas explorado y evocó con melancolía el legendario mundo incaico que los Comentarios reales le habían permitido descubrir. Desde entonces trataría de conciliar el legado incásico y el español, cuyos restos daban cuenta del pasado esplendor en contraste con la decadencia de la República. Exiliado durante el «oncenio» de Leguía, la nostalgia del Perú reafirmó su voluntad de arraigarse en esa doble tradición: a la vez que revisaba la historia cultural peruana a través de los linajes llegados al país desde el siglo XVI, y entre los que se contaban sus propios antepasados, en El Perú histórico $y$ artístico. Influencia y descendencia de los montañeses en él dedicó no pocas páginas a divulgar sus conocimientos sobre el pasado prehispánico, incluidas las manifestaciones culturales quechuas -las de «una raza dulce, soñadora y quejumbrosa, fina aun en medio de su presente degradación» ${ }^{56}-$, de las que se mostraba buen conocedor. El Inca Garcilaso de la Vega, en cuya personalidad «se fundieron amorosamente Incas y Conquistadores» ${ }^{57}$, necesariamente tenía que convertirse ya en "precursor magnífico» de esa conjunción, en la que ahora se cifraba la verdadera nacionalidad peruana.
Las aportaciones de los novecentistas al conocimiento de la literatura del Perú -incluida la edición del drama Ollantay-fueron más ricas que lo que estas páginas permiten precisar. Como De la Riva-Agüero al ocuparse de Comentarios reales, todos entendieron que la historia literaria y artística, «manifestación de la vida afectiva de un pueblo», podía ser «más segura clave» que la historia política para conocer la índole de ese pueblo ${ }^{58}$. Algunas opiniones incluidas en Carácter de la literatura del Perú independiente -primera gran aportación al análisis de la historia literaria del país- dieron pie a las acusaciones de colonialismo que se habrían de esgrimir contra ellos: De la Riva-Agüero explicaba la literatura nacional en función del genio criollo y de la imitación de otras literaturas, lo que lo llevó a concluir que «la literatura peruana forma parte de la castellana» ${ }^{59}$, por razones de idioma y de tradición, y por el carácter aún incipiente de tal literatura. También sus propuestas para el futuro se prestarían a la polémica, sobre todo entre los partidarios del «inkaísmo»: «El sistema que para americanizar la literatura se remonta hasta los tiempos anteriores a la Conquista, y trata de hacer revivir poéticamente las civilizaciones quechua y azteca, y las ideas y los sentimientos de los aborígenes, me parece el más estrecho e infecundo. No debe llamársele americanismo sino exotismo» ${ }^{60}$, dictaminó, sin dejar de apreciar la individualidad artística de la que cada escritor fuese capaz, ni de advertir las ventajas de una «extranjerización» futura e inevitable. No ignoraba la importancia de la mejor cultura francesa, cuyo conocimiento animaba a conjugar con el de otras literaturas -alemana, inglesa, italiana-, ni quería romper los lazos con el pasado nacional. No es extraño, pues, que terminara recomendando "conservar el legado de la tradición española, estudiar a los autores clásicos de las literaturas extranjeras y estudiar a los clásicos latinos» ${ }^{61}$, como componente fundamental de una sólida formación literaria. Desde entonces las opiniones de los novecentistas sobre la literatura peruana se prestarían a una discusión de virulencia creciente. Ventura García Calderón, autor de los comentarios y la selección reunidos en 1910 en Del romanticismo al modernismo. Prosistas $y$ poetas peruanos, fue víctima del primer ataque violento, a cargo de Federico More, quien en 1916, en los números 2 y 3 de la revista $\mathrm{Co}^{-}$ lónida, dedicó «La hora undécima del señor 
don Ventura García Calderón» a subrayar los errores y las ausencias que decidió encontrar en La literatura perwana (1535-1914), una breve historia que el agredido había dado a conocer en 1914. La atención dedicada a la literatura colonial y a Ricardo Palma permitían considerar a su autor "colono de España» y recriminar su olvido de la tradición cultural indígena: «Cuando el señor García Calderón vaya hasta el más helado y agreste rincón andino y escuche de labios del aborigen una y mil leyendas, verá que hay diferencia entre la literatura peruana, honda, triste, fuerte y sobria, y la literatura colonial hecha por frailes, tahúres y andróginos» ${ }^{62}$. Empezaba a gestarse la atmósfera intelectual adversa que silenciaría a los novecentistas.

En cuanto a la orientación literaria potenciada por la generación del novecientos, merecen atención las preferencias de De la Riva-Agüero por un americanismo descriptivo atento a los paisajes y a la naturaleza, aunque no desdeñase la opción regional, destinada a captar las costumbres populares antes de que desapareciesen, ni la posibilidad de basar en la conquista y la colonia creaciones de inspiración histórica. Eran preferencias que buena parte de los escritores posmodernistas hispanoamericanos compartían, frente a los modernistas o afrancesados que para De la Riva-Agüero «se imaginan que rivalizan con Rubén Darío, poeta exquisito pero funestísimo maestro; admirable en sí a título de curiosidad singular y atractiva, pero aborrecible como jefe de escuela» ${ }^{63}$. De los cuatro novecentistas comentados, Ventura García Calderón fue el más afectado por ese galicismo mental, notorio en sus ensayos y cuentos iniciales, y aún comprobable en 1920 tanto en las prosas y versos reunidos en Cantilenas como en los ensayos -casi todos determinados por la guerra europea- de Bajo el clamor de las sirenas. Su acercamiento a la realidad peruana se concretaría sobre todo en La venganza del cóndor, volumen de cuentos publicado en Madrid en 1924. Inquietantes y violentos, los territorios de la selva y de la sierra encontraron cabida en esos relatos, aderezados a veces con humor y casi siempre con el interés también mundonovista por atmósferas de leyenda y misterio. En alguno de ellos se recuperó los tiempos del virreinato, aunque eso no modifica la impresión general de que el «colonialismo» peruano se manifestó menos en la creación literaria que en los

estudios literarios e históricos destinados a comprender el pasado, a veces para liberarse de él y casi siempre, como Belaúnde también había pedido, para reconstruir con piadosa mano sus reliquias dispersas y conservar con amor sus formas profanadas ${ }^{64}$.

Como se habrá podido deducir, la generación peruana del novecientos no puede reducirse al espíritu colonialista y conservador que le atribuyeron sus detractores, dando a veces pie a réplicas brillantes. Entre ellas se contó la provocada por las acusaciones de Mariátegui: particularmente afectado por las descalificaciones -citas de su folleto $L a$ vida universitaria (1917) sirvieron para que resultara «vinculado por su educación y su temperamento a la casta feudal» ${ }^{65}-$, Belaúnde respondió desde la revista Mercurio Peruano con los artículos que en 1931, con otros capítulos dedicados a enjuiciar severamente la dictadura de Leguía y uno más sobre «La necesidad de una filosofía constructiva», conformarían el citado volumen $L$ a realidad nacional. Su respetuosa revisión de 7 ensayos de interpretación de la realidad peruana-Mariátegui lo entendió asít6- le permitió volver sobre sus planteamientos antiguos e introducir matices nuevos, en particular los derivados de la doctrina social de la Iglesia que ahora constituía para él una referencia fundamental y que resultaría determinante en sus escritos posteriores. La incomprensión que descubría en su entorno lo decidió un año después a reunir en Meditaciones peruanas algunos de sus ensayos anteriores al destierro junto a otros recientes. De poco sirvió: el tolerante «tradicionalismo dinámico y evolutivo» ${ }^{67}$ con que los novecentistas habían tratado de regenerar el país parecía definitivamente enterrado por la agresividad con que la generación del centenario había irrumpido en el espacio cultural y político nacional. Hoy la revisión de sus aportaciones invita a pensar que, al olvidarlas, el Perú algo perdió, quizá para siempre.

\section{2}

Federico More, «La hora undécima del señor don Ventura García Calderón», en Colónida, año I, tomo I, núm. 2 (pp. 33-39), p. 35. Edición

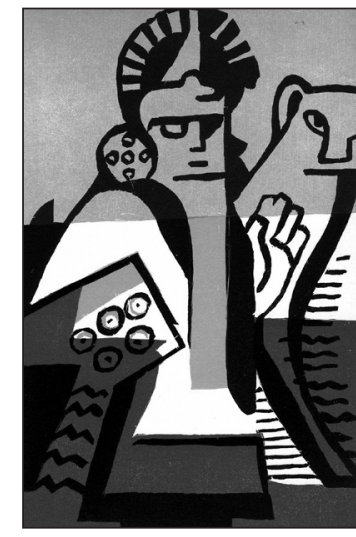

Portada de Ollantay.

63

Carácter de la literatura del Perú independiente, op. cit., p. 233.

64

"La historia», en op. cit., p. 17. El espíritu "colonialista» más estricto podría encontrarse en las «crónicas evocativas» que José Gálvez, miembro también de la generación del novecientos, reunió en Una Lima que se va (1921), volumen que encontraría continuación con sus prosas y versos de Estampas limeñas (1935). Tras las huellas de Palma, Gálvez «le añade profundidad a la nostalgia, insiste en la queja por el sentimiento de la pérdida y configura el discurso idealizador de la Lima colonial». Eva $M^{a}$ Valero Juan, Lima en la tradición literaria del Perú. De la leyenda urbana a la disolución del mito, Lleida, Editions de la Universitat de Lleida, 2003, p. 127.

65

7 ensayos de interpretación de la realidad peruana, op. cit., p. 98.

66

«Recuerdo con satisfacción que el propio Mariátegui apreció el espíritu que animaba mi crítica, al agradecerme en la dedicatoria de su libro la deferencia personal que revelan mis ensayos», anotaría Belaúnde al lamentar "la triste desaparición del gran escritor socialista». La realidad nacional, op. cit., p. 136.

67

Belaúnde, "La historia», en op. cit., p. 34.

facsimilar con prólogo de Luis Alberto Sánchez y una carta de Alfredo González Prada acerca de Abraham Valdelomar y el movimiento colónida Lima, Ediciones Cope, 1981.
La generación del novecientos y los discursos de identidad TEODOSIO FERNÁNDEZ 